\title{
The Analysis of Translators from the Perspective of Deconstruction
}

\author{
Xin Li \\ School of Foreign Languages, Tianjin University of Technology \\ Hongqi Road 263, Nankai Area, Tianjin 300191, China \\ E-mail: 1sxysys1314@yahoo.cn \\ Shi Cheng \\ School of Foreign Languages, Tianjin University of Technology \\ Hongqi Road 263, Nankai Area, Tianjin 300191, China \\ E-mail: 1sxysys1314@yahoo.cn
}

Received: March 24, 2011 Accepted: April 20, 2011 doi:10.5539/ass.v7n5p258

\begin{abstract}
Deconstruction is a revolutionary theory that challenges the traditional Western philosophy. Applied into translation theory, it rejects the central position of the source text and enhances the status of both the target text and translators. This theory explores a totally new field for translation studies. This paper will make an analysis of translators from the perspective of deconstruction by quoting Jacques Derrida, Douglas Robinson and Lawrence Venuti's views.
\end{abstract}

Keywords: Deconstruction, Translators, Ethics of translation, Resistance

Deconstruction is a doubt-blade academy weapon that both brings fresh air to the translation study and exerts powerful impact to the traditional translation theory. It is characterized by enhancing the status of both target text and translator. In the traditional translation theory, the source text is generally taken for granted as the logos or the center in relation to the target text, whereas the target text is considered as the supplement of the source text. However, from deconstructionist's point of view, logos doesn't exist, and the supplement is not the secondary. Both the source text and target text are closely related to each other and supplement to each other. This postulation magically raises the status of the TT from the subordinate to the balanceable or even superior to the original text. Accordingly, the translator' status has also been largely enhanced. This paper will make an analysis of translator from the perspective of deconstruction by quoting Jacques Derrida, Douglas Robinson and Lawrence Venuti's views.

\section{Deconstruction}

\subsection{The History and Source of Deconstruction}

Deconstruction is the name given by French philosopher Jacques Derrida to an approach (whether in philosophy, literary analysis, or in other fields) which rigorously pursues the meaning of a text to the point of undoing the oppositions on which it is apparently founded, and to the point of showing that those foundations are irreducibly complex, unstable or impossible.

Deconstruction generally operates by conducting close textual readings with a view to demonstrating that the text is not a discrete whole but that it instead contains several irreconcilable, contradictory meanings. This process shows that any text has more than one interpretation; that the text itself links these interpretations inextricably; that the incompatibility of these interpretations is irreducible; and thus that interpretative reading cannot go beyond a certain point. Derrida refers to this point as an aporia in the text, and terms deconstructive reading "aporetic." J. Hillis Miller has described deconstruction this way: "Deconstruction is not a dismantling of the structure of a text, but a demonstration that it has already dismantled itself. Its apparently-solid ground is no rock, but thin air."

In Of Grammatology (1967) Derrida introduces the term deconstruction to describe the manner that understanding language, as "writing" (in general) renders infeasible a straightforward semantic theory. In first using the term deconstruction, he "wished to translate and adapt to my own ends the Heideggerian word 
Destruktion or Abbau". Martin Heidegger's philosophy developed in relation to Edmund Husserl's, and Derrida's use of the term deconstruction is closely linked to his own (Derrida's) appropriation of the latter's understanding of the problems of structural description.

\subsection{Différance}

Crucial to Derrida's work is the concept of différance, a complex term which refers to the process of the production of difference and deferral. According to Derrida, all difference and all presence arise from the operation of différance. He states that: To "deconstruct" philosophy [...] would be to think - in the most faithful, interior way - the structured genealogy of philosophy's concepts, but at the same time to determine - from a certain exterior [...] - what this history has been able to dissimulate or forbid [...] By means of this simultaneously faithful and violent circulation between the inside and the outside of philosophy [...a] putting into question the meaning of Being as presence

To deconstruct philosophy is therefore to think carefully within philosophy about philosophical concepts in terms of their structure and genesis. Deconstruction questions the appeal to presence by arguing that there is always an irreducible aspect of non-presence in operation. Derrida terms this aspect of non-presence différance. Différance is therefore the key theoretical basis of deconstruction. Deconstruction questions the basic operation of all philosophy through the appeal to presence and différance therefore pervades all philosophy. Derrida argues that différance pervades all philosophy because "What defers presence [...] is the very basis on which presence is announced or desired in what represents it, its sign, its trace." Différance therefore pervades all philosophy because all philosophy is constructed as a system through language. Différance is essential to language because it produces "what metaphysics calls the sign (signified/signifier)

\section{Views on Translator}

\subsection{Douglas Robinson}

Douglas Robinson is an active and influential translation theorist in contemporary Western translation academia. His works include Translation and Taboo, What Is Translation? Centrifugal Theories, Critical Interventions, Translation and Empire: Postcolonial Theories Explained, Who Translates? Translator Subjectivities beyond Reason, and so on. The Translator's Turn is his first book on theory of translation based on the premises that translation is (a) primarily somatic, grounded not in abstract mental operations but in the body, and (b) a turning rather than a bridging, a swerving from the source text off in new directions rather than the construction of a stable structure of equivalence. In two parts: (1) "Dialogical Bodies," covering the somatics and dialogics of translation, with sections on the idio- and ideosomatics of translation, Augustine, Luther, Goethe, Buber, and Bakhtin; (2) "Dialogical Turns," covering the tropics (metonymy, synecdoche, metaphor, irony, hyperbole, and metalepsis) and ethics (conversion, reversion, subversion, perversion, aversion, diversion, conversation) of translation.

\subsubsection{Translators in Translation Process}

At the very beginning of his book The Translator's Turn, Robinson proposes that "it seems undeniable that translation is largely an intuitive process." Good translators choose words and phrases by reference not to some abstract system of intellectualized rules, which most of us have never internalized in the first place, but rather to "messages" or impulses sent by the body: a given word or phrase feels right. Intuitively, not just for the translator but for all languages users, sense is not cognition but sensation.

The translator's intuitive genius must not be hogtied by theory; the theorist's analytic systematicity must not be muddled by too much attention to practical detail. The translator who stands too close to theory produces lifeless mathematical travesties of translation; the theorist who stands too close to practices pathetically local and unanalyzed, unsystematic travesties of theory.

Then Robinson states "It seems to me that the only way to put an end to this situation is to insist, in both our theorizing and our translating, on an integration of warring opposites: feeling and thought, intuition and systematization."

Traditionally, translators imagine their ethical task as one of introversion, self-effacement, becoming a window between SL text and TL receptors that the TL receptor will not even recognize as a window. No personality; no self-advertisement. This is another reason for the low status of translation.

It is time to offer translators tools, not rules-and tools derived not from Christian theology and the dogmatic demands placed on Bible translating, as has largely been the case in Western translation theory, but from what translators actually do when they translate. 


\subsubsection{The Internal Response of Translator}

To speak a foreign language well you have to feel the word. Part of learning a language well is watching what native speakers' bodies do when they speak it: how they move their mouths, how they gesture and shift their weight, how they stumble over words, when and how they pause. But even that will not be enough if it is done mechanically. You have to do more than watch; you have to intuit, sense what their bodies are doing inside, sense how they feel when they speak. Obviously, something like this imaginative, identificatory selfprojection into the body of a native speaker is a primary requirement for the good translator as well. If the translator does not feel the body of the SL text, you will have little chance of generating a physically tangible or emotionally alive TL text. The TL text you create will read like computer-generated prose: no life, no feeling.

There seems to be an unwritten rule among translation theorists, in fact, that for theory somatic response is the kiss of death. The only person who would dare talk about equivalence in terms of feeling, intuition, body response, is a translator; and among translators, probably only a literacy translator; and among literary translators, only a maverick poet with a reputation for erratic brilliance. A theorist who talked that way would surely reveal his or her ignorance, his or her inadequate powers of intellection, abstraction, generalization, systematization. Theorists are supposed to be scientists, and scientists do not play around with real bodies. If they have to do with bodies at all, they must be what Paul calls "spiritual bodies," safely removed to an idealized realm of forms.

A mediocre translator, again, will strive for logical consistency by suppressing somatic confusion; a great translator will not shrink from somatic confusion, somatic inconsistency, will not retreat into protective intellection, but will boldly flesh out the contradictory and conflicting body of his or her response with the overriding conviction that, if it all came from the guts, it is all of a piece.

\subsubsection{The Ethics of Translation}

Robinson actualizes his observation into the generalization and description of various ethics of translation in order to explain the complexity of translation. He proposes his own ethics of translation containing the affix 'vert' by reforming the Christianity concepts, such as diversion, aversion, perversion, eversion, reversion, controversion, conversion, and so forth.

\section{(1) Introversion and Extroversion}

Introversion means that the translator conveys the meaning of the SL text to the TL receptor. The translator is a window through which the TL receptor can perceive the SL meaning without distortion or obstruction. The translator is not person, with personal experiences, personal desires, and personal preferences. The translator is a vehicle or an instrument. However, translator are not born tools, the only way for a translator to get from personhood to toolhood is by denying his or her own personality - by systematically suppressing personal experiences, personal desires, personal preferences.

Extroversion means translators express themselves, do creative versions of texts, importing personal meanings into the SL writer's intention.

\section{(2) Conversion and Advertising}

It is implicit in the institutional hegemony of a Christian concept of translation as conversion. The translator's task is to stay out of the way so that God can do his work on the TL reader. Stand between God and the TL reader, certainly, but invisibly: as an instrument, an introvert, a window. The purpose behind this is to help God(conceived as the Ultimate SL writer) convert the TL reader.

Advertising is the direct bourgeois descendant of Christian proselytizing anyway, the capitalist version of what in the Middle Ages was done by the Catholic church, so it is not surprising that advertisers expect translators to be proselytizers. In some sense, then, advertising translation is capitalist Bible translation. At deep level, the aim of advertising translation is to convert the TL reader or viewer into a buyer of the SL company's product-or rather, into a believer in the company's product, so that he or she will keep buying it.

(3) Reversion

In any case, the specific sense of reversion is the romantic one of returning humanity to an original state of unity, one we all once occupied but have since lost- a state that persuader has not attained him-or herself, obviously, but wants us all to try to return to, or wants the translator as romantic poet-hero to try to teach us to return to.

\section{(4) Subversion}

In terms of the translator's dialogue with the TL receptor, subversion means an undermining or overthrowing of some fundamental assumption or expectation that the receptor brings to the translation or to translation in 
general.

The subversive translator translates-at least in part-shock TL receptors out of complacent familiarity with the text, and shock has limited historical duration. Old subversions quickly become merely quaint.

\subsection{Lawrence Venuti}

Lawrence Venuti, Professor of English, works in early modern literature, British, American, and foreign poetic traditions, translation theory and history, and literary translation. He is the author of Our Halcyon Dayes: English Prerevolutionary Texts and Postmodern Culture (1989), The Translator's Invisibility: A History of Translation (1995), and The Scandals of Translation: Towards an Ethics of Difference (1998). He is the editor of the anthology of essays, Rethinking Translation: Discourse, Subjectivity, Ideology (1992), and of The Translation Studies Reader ( $2^{\text {nd }}$ ed. 2004), a survey of translation theory from antiquity to the present.

\subsubsection{Invisibility}

"Invisibility" is the term used by Venuti to describe the translator's situation and activity in contemporary Anglo-American culture. It refers to two mutually determining phenomena: one is an illusionistic effect of discourse, of translator's own manipulation of English; the other is the practice of reading and evaluating translations that has long prevailed in the UK and the US, among other cultures, both English and foreign language.

Under the regime of fluent translating, the translator works to make his or her work "invisible," producing the illusory effect of transparency that simultaneously masks its status as an illusion: the translated text seems "natural," i.e., not translated.

As to the reason of he translator's invisibility, Venuti states that:

"The translator's invisibility is also partly determined by the individualistic conception of authorship that continues to prevail in Anglo-American culture. The translator's invisibility is thus a weird self-annihilation, a way of conceiving and practicing translation that undoubtedly reinforces its marginal status in Anglo-American culture."

The translator's shadowy existence in Anglo-American culture is further registered, and maintained, in the ambiguous and unfavorable legal status of translation, both in copyright law and in actual contractual arrangements, both in copyright law and in actual contractual arrangements.

The translator's authorship is never given full legal recognition because of the priority given to the foreign writer in controlling the translation-even to the point of compromising the translator's rights as a British or American citizen.

\subsubsection{Foreignizing Translation}

In his book Venuti quotes Schleiermacher's view as significant basis of his theory:

"there are only two. Either the translator leaves the author in peace, as much as possible, and moves the reader towards him; or he leaves the reader in peace, as much as possible, and moves the author towards him. Admitting that translation can never be completely adequate to the foreign text," Schleiermacher allowed the translator to choose between a domesticating method, an ethnocentric reduction of the foreign text to target-language cultural values, bringing the author back home, and a foreignizing method, an ethnodeviant pressure on those values to register the linguistic and cultural difference of the foreign text, sending the reader abroad.

Foreignizing translation in English can be a form of resistance against ethnocentrism and racism, cultural narcissism and imperialism, in the interests of democratic geopolitical relations.

\subsubsection{Translator's Strategies}

Venuti lists out what knowledge translators should possess. Yet alternative theories and practices of translation are worth recovering because they offer contemporary English-language translator exemplary modes of cultural resistance, however qualified they must be to serve a new and highly unfavorable scene. The domesticating translating that currently dominates Anglo-American literary culture, both elite and popular, can be challenged only by developing a practice that is not just more self-conscious, but more self-critical. Knowledge of the source-language culture, however expert, is insufficient to produce a translation that is both readable and resistant to a reductive domestication; translators must possess a commanding knowledge of the diverse cultural discourses in the target language, past and present. And they must be able to write them.

Venuti proposes his own theory should translators should adopt the resistance strategies. The translator, who 
works with varying degree of calculation, under continuous self-monitoring and often with active consultation of cultural rules and resources, may submit to or resist dominant values in the target language, with either course of action susceptible to ongoing redirection. Resistance assumes an ideology of autonomy, locating the alien in a cultural other, pursuing cultural diversity, foregrounding the linguistic and cultural differences of the source-language text and transforming the hierarchy of cultural values in the target language.

Translators must also force a revision of the codes-cultural, economic, legal- that marginalize and exploit them. They can work to revise the individualistic concept of authorship that has banished translation to the fringes of Anglo-American culture, not only by developing innovative translation practices in which their work becomes visible to readers, but also by presenting sophisticated rationales for these practices in prefaces, essays, lectures, interviews.

\section{Conclusion}

Deconstruction as a major philosophical theory has exerted strong influence upon translation studies. Its advocacy of enhancing translators' status to an extreme aroused fierce debate since it was introduced in 1990s. Some scholars in favor of deconstruction pointed out that" translation studies from deconstruction perspective enhance the status of translator to a large extent," which is a welcome opposition against the traditional view of regarding translators as slaves; while others against it argue that deconstruction endows translators with overloaded power which results in the dissolution of meaning and even nihilism. It must be admitted that deconstruction, like any other school of theory, has its defects as well as its merits, as we mentioned above, and what we have explored in this essay is based on its very merits that encourage different voices towards translation. Moreover, by stressing the undecidability of meaning and the close relation between context and meaning, deconstructionists help to throw fresh insight into the relation between the original text and the translation, endow translators with the right of rewriting, and therefore give great prominence to their subjectivity which has long been denied in the academic world of translation studies.

\section{References}

Guo, Jian zhong. (2000). Contemporary American Translation Theory. Wuhan: Hubei Education Press.

Han, Ziman. (2008). Subjectivity Exploration of Decomposed Translator, Reading Robinson. Who translated. Journal of Xi'an International Studies University.

Hatim, B. \& Mason, I. (2005). Discourse and the Translators. Translated by Kefei Wang. (2005). Beijing: Foreign Language Teaching and Research Press.

Luyan. (2007). The Analysis of Translator's Subjectivity from the Perspective of Deconstruction. Central China Normal University.

Robinson, D. (2006). The Translator's Turn. Beijing: Foreign Language Teaching and Research Press.

Venuti, L. (2004). The Translator's Invisibility: A History of Translation. Shanghai: Shanghai Foreign Language Education Press.

Yang, Jianhua. (2009). Western Translation Theory Series. Tianjin: Tianjin University Press. 